\title{
GREEN BONDS AS MODERN FINANCIAL INSTRUMENTS
}

\author{
Katarzyna ŻAK \\ University of Economics, Katowice; katarzyna.zak@ue.katowice.pl, ORCID: 0000-0002-9212-7206
}

Purpose: The purpose of the paper is to present and analyse the development of green bonds issued on the Polish and international market in 2015-2021.

Design/methodology/approach: The research methods used in the paper include the survey of Polish and foreign literature as well as the analysis of data from secondary sources. Desk research analysis was based on numerical data contained in the Climate Bonds Initiative database.

Findings: The result of the conducted research is an indication of trends concerning the development of the green bond market and the main leaders on the international market. The position of Poland as an issuer of this type of securities is presented against this background. Research limitations/implications: The presented findings encourage further research to systematize data on green finance in Poland and the issue of green bonds from the point of view of the adopted criteria for their division.

Practical implications: The analysis and assessment of the causes and effects of the issue of green bonds, especially on international markets, should be a kind of leverage to popularize this method of financing pro-ecological projects in Poland, especially among entrepreneurs and local governments.

Social implications: The use of the presented data, analyses and conclusions should imply further actions and strategies of various entities necessary to implement the concept of sustainable development, especially green financing. The implementation of green bonds should result in the development of the capital market on the one hand, and on the other hand, contribute to the effective implementation of pro-ecological projects.

Originality/value: The article synthetically presents the significance of the concept of green finance. It deals with current issues related to green bonds as well as global and domestic trends in their application.

Keywords: green bond, green finance, green economy, environment, ecology.

Category of the paper: General review. 


\section{Introduction}

The prospect of a global ecological crisis, ironically treated a few years ago as catastrophic propaganda by a group of ecologists, is today an important subject of public debate. It begins to be taken for granted by recognized groups of researchers, as well as major political leaders of the modern world, the influential media and the vast majority of the public. Numerous media reports and publications inform about the climate crisis, climate warming, and the catastrophic effects it will have on our civilization. However, attention should be paid to the fact that negative climate change is only part of a larger whole, i.e., the environmental crisis (also known as the ecological crisis). It is most often perceived as an unfavourable result of civilization development. During this development, nature was ruthlessly subordinated to the goals pursued by man. Its consequence is the greenhouse effect, pollution of the natural environment, reduction of biodiversity or depletion of non-renewable natural resources (Bieniok, 2020).

The concept of sustainable development, and especially that part of it, the main goal of which should be an immediate, persistent and constant endeavour to restore and then maintain the balance between man and nature is to be the antidote to the situation that has arisen. The implementation of such an approach is the result of realizing by contemporary societies of the risk caused by an inappropriate, purely utilitarian, non-accountable human attitude towards nature, which was developed in the era of the paradigm of unlimited civilization growth.

In the case of enterprises, the importance of the idea of corporate social responsibility, i.e., the concept of business conduct in which responsible economic development is reconciled with social and environmental issues is growing. This is not an easy task, as it requires changing the current philosophy of running a business and searching for various tools that will support the necessary changes. Green finance and their instruments - green bonds are one of such solutions.

The purpose of the paper is to present and analyse the development of specialized financial instruments in the form of green bonds issued on the Polish and international market in 2015-2021.

The research methods used in the paper include the survey of Polish and foreign literature, as well as the analysis of data from secondary sources. The desk research analysis was based on the numerical data contained in the Climate Bonds Initiative database. 


\section{The role of green finance}

Sustainable development issues are more and more often reflected in documents and recommendations from various conferences, in the strategies of major financial institutions, social organizations, corporations and their activities. Today, the financial sector plays a key role in supporting and implementing the sustainable development policy, directing cash flows to those entities that prepare and implement sustainable development strategies (Caldecott et al., 2014). In addition to economic and social goals, special financial support covers activities aimed at inhibiting the negative effects of the global environmental crisis. As L. Dziawgo (2014) and B. Ryszawska (2020) state, the modern financial market engages in supporting the pro-ecological transformation of society as well as the economy, and is evolving towards "greening", which manifests itself in in the development of such "green instruments" as carbon finance, green stimulus funds, microfinancing, green bonds, international and national climate funds, green infrastructure, real estate funds, and socially responsible equity funds. The shift to sustainable development transforms the economy towards a green, low carbon, resource efficient and combating climate change economy. In this context, apart from the concept of sustainable finance, the concept of green finance appears (it should be added that many authors equate and use these terms interchangeably). To fully understand the difference between these concepts, it is important to note what goals they support. Sustainable finance supports sustainable development, while green finance supports the green economy, green growth, low carbon and resource efficiency (Świeszczak, 2020). In the available literature on the subject, there are many different definitions of this concept. Some of them are presented here. At the conference in Davos green finance was defined as any structured financial activity a product or service - that's been created to ensure a better environmental outcome. It includes an array of loans, debt mechanisms and investments that are used to encourage the development of green projects or minimize the impact on the climate of more regular projects. Or a combination of both. Typical green finance projects concern: renewable energy and energy efficiency, pollution prevention and control, biodiversity conservation, circular economy initiatives and sustainable use of natural resources and land (WEF, 2020). Another by definition states that green finance is a broad term that can refer to financial investments flowing into sustainable development projects and initiatives, environmental products, and policies that encourage the development of a more sustainable economy. Green finance includes climate finance but is not limited to it. It also refers to a wider range of „other environmental objectives, for example industrial pollution control, water sanitation, or biodiversity protection. Mitigation and adaptation finance is specifically related to climate change related activities: mitigation financial flows refer to investments in projects and programs that contribute to reducing or avoiding greenhouse gas emissions (GHGs) whereas adaptation financial flows refer to investments that contribute to reducing the vulnerability of goods and persons to the effects of 
climate change (Höhne et al., 2012). According to the definition of U. Volz (2015) green finance comprises all forms of investment or lending that consider environmental impact and enhance environmental sustainability. A key element of GF is sustainable investment and banking, where investment and lending decisions are taken on the basis of environmental screening and risk assessment to meet environmental sustainability standards. On the other hand, for the banking sector, green finance is defined as financial products and services, under the consideration of environmental factors throughout the lending decision making, ex-post monitoring and risk management processes, provided to promote environmentally responsible investments and stimulate low-carbon technologies, projects, industries and businesses (PWC, 2013).

In conclusion, it can be said that the role of green finance is to redirect capital to a green, environmentally sustainable economy and it includes (Kotecki, 2020; Lindenberg, 2014):

- the financing of public and private green investments (including preparatory and capital costs) in the following areas:

$\checkmark$ environmental goods and services (such as water management or protection of biodiversity and landscapes),

$\checkmark$ prevention, minimization and compensation of damages to the environment and to the climate (such as energy efficiency or dams);

- the financing of public policies (including operational costs) that encourage the implementation of environmental and environmental-damage mitigation or adaptation projects and initiatives (for example feed-in-tariffs for renewable energies);

- components of the financial system that deal specifically with green investments, such as the Green Climate Fund or financial instruments for green investments (e.g., green bonds and structured green funds), including their specific legal, economic and institutional framework conditions.

\section{Green bonds - the issue conceptualisation}

In order to finance projects related to the green economy, it is necessary to obtain appropriate funds for this purpose. Green bonds are now one of the most popular instruments of "green" financing. Although they have been present on the market since 2007, their uniform definition has not yet been formulated. Table 1 contains proposals presented by various authors and institutions. 
Table 1.

Green bonds - proposals for the definition

\begin{tabular}{|c|l|}
\hline $\begin{array}{c}\text { Authors/Institutions } \\
\text { R. Della Croce, } \\
\text { C. Kaminker, F. Stewart }\end{array}$ & $\begin{array}{l}\text { Green bonds are fixed income securities, the intention of which is to use the funds } \\
\text { obtained through their issue for financing projects aimed at the development of } \\
\text { economy which is low-carbon and resilient to climate change. }\end{array}$ \\
\hline C. Flammer & $\begin{array}{l}\text { Green bonds are innovative securities that are debt instruments. Funds from their } \\
\text { issue are allocated to financing low-emission, climate-friendly projects; they are } \\
\text { most often issued by corporations, local government units, governments and } \\
\text { supranational institutions. }\end{array}$ \\
\hline J. Fu, S. Li, A.W. Ng & $\begin{array}{l}\text { A green bond is a type of bond the proceeds of which should be used to finance or } \\
\text { refinance green projects. The authors indicate both standard financing and } \\
\text { refinancing, i.e., the transfer of funds to already implemented pro-ecological } \\
\text { projects. Such an extension of the definition gives more options for the use of green } \\
\text { debt. Moreover, it is directly defined as a type of bond in the financial market. }\end{array}$ \\
\hline $\begin{array}{c}\text { World Bank } \\
\text { The International Capital } \\
\text { Market Association } \\
\text { (ICMA) }\end{array}$ & $\begin{array}{l}\text { Green bonds are debt securities that, apart from their standard financial } \\
\text { environmental purpose of the issue. } \\
\text { the full or partial financing or refinancing of projects leading to environmental } \\
\text { benefits. }\end{array}$ \\
\hline
\end{tabular}

Elaboration based on: (Della Croce et. al., 2011), (Flammer, 2019), (Fu et al., 2020), (World Bank, 2015), (International Capital Market Association, 2019).

The fact that green bonds are issued in order to obtain capital for financing/refinancing projects aimed at a positive change in the condition of the natural environment is their basic and at the same time distinguishing feature. They are debt securities that can be described with the use of such parameters as maturity or coupon that are standard for classic bonds. Therefore, it can be said that only the first of the mentioned attributes, i.e., the use of the collected funds specifically for supporting nature, clearly and visibly distinguishes these bonds from their classic equivalents (Laskowska, 2020).

The presence of green bonds on the financial market for the last 14 years caused the emergence of the so-called green bond taxonomy. It represents the regulatory framework for the issuance of these financial instruments. It includes a system of rules and standards that define the Green Bond and its features that provide the investor with a proof of correctness, i.e., certificate stating the environmental purpose of the capital. The use of this framework increases the efficiency, transparency, comparability and credibility of the green bond market and encourages investors to issue and invest in them. The most popular emission standards for these instruments are those developed by the International Capital Market Association (ICMA) and the Climate Bonds Initiative (CBI). A group of technical experts for sustainable finance (TEG Technical Expert Group) has also been established in the European Union. Their task is to define the criteria that must be met for a bond to be classified as green (EU GBS The European green bond standard). The proposed standard model defines four basic requirements (European Commission, 2021): 
- Taxonomy-alignment: The funds raised by the bond should be allocated fully to projects that are aligned with the EU taxonomy.

- Transparency: Full transparency on how the bond proceeds are allocated through detailed reporting requirements.

- External review: All European green bonds must be checked by an external reviewer to ensure compliance with the Regulation and taxonomy alignment of the funded projects.

- Supervision by the European Securities Markets Authority (ESMA) of reviewers: External reviewers providing services to issuers of European green bonds must be registered with and supervised by the ESMA. This will ensure the quality of their services and the reliability of their reviews to protect investors and ensure market integrity.

In Poland, green bonds and their issuance, like any other bond, with the exception of bonds issued by the State Treasury and the National Bank of Poland, are subject to the requirements of the Act on Bonds. The Act determines the rules for the issuance, changes to the terms of issue, sale, purchase and redemption of bonds (Dz.U. [Journal of Laws], 2020).

Presenting the typology of green bonds completes the outline of knowledge about them. Table 2 contains the basic classifications of these instruments and the criteria for their distinction.

Table 2.

Classifications of green bonds

\begin{tabular}{|c|ll|}
\hline $\begin{array}{c}\text { Criterion for } \\
\text { differentiation }\end{array}$ & \multicolumn{1}{c|}{ Types of green bonds } \\
\hline & - & green supranational, quasi-state and agency bonds, \\
Type of issuer & - & green corporate bonds, \\
& - & green bonds of the financial sector, \\
& - & green treasury (government) bonds.
\end{tabular}

Elaboration based on: (Laskowska, 2020). 


\section{Green bonds in the perspective of statistical data - a synthetic approach}

Currently, green bonds are used all over the world. It has been 14 years since the first were issued by the European Investment Bank (EIB) (Laskowska, 2019). Based on the statistical database collected by the Climate Bonds Initiative, the increasing global value of green bonds has been observed year by year (Fig. 1). In 2020, their value was almost six and a half times higher in comparison with 2015. Also, the data for the first half of 2021 suggest that at the end of December another record value will be achieved, as their global value at the end of June 2021 already accounted for nearly $80 \%$ of the value of the previous year.

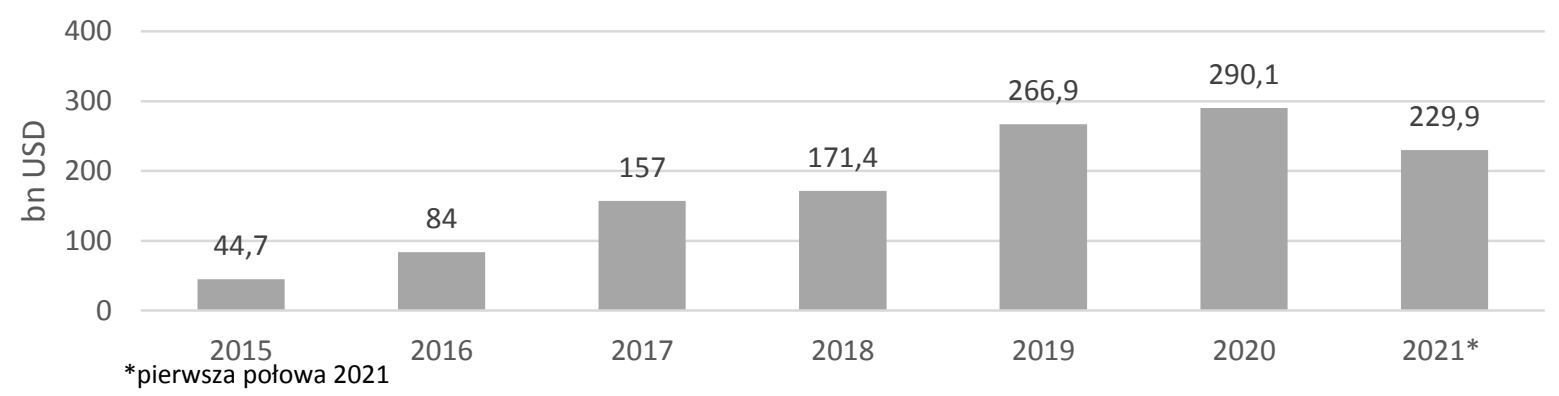

Figure 1. Global value of green bonds in 2015-2021. Source: Climate Bonds Initiative.

As of 2007, the global cumulative value of green bonds is USD 1,303.3 billion. When referring the issue of green bonds to various regions of the world, it should be noted that their highest cumulative value is held by European countries (USD 690.4 billion) as well as the USA and Canada (USD 394.7 billion), while they appear to a very limited extent in the African countries, where this value is estimated at USD 104.3 billion. A similar trend can be observed when analysing the successive years. For example, in 2020 Europe is the leader with USD 156 billion, North America comes second with USD 61.5 billion, Asia Pacific ranks third with USD 53.2 billion, and finally Latin America with USD 7.9 billion. African countries have a relatively small value, i.e., USD 1.2 billion. Considering the level of economic development, it can be concluded that $80 \%$ of green bonds are related to developed markets and $16 \%$ to emerging markets. It is estimated that currently the cumulative global value of supranational green bonds constitutes $7.7 \%$ of their total value, and this share is diverse in the subsequent years of the analysis. The main issuers of green bonds on the global market represent non-financial corporations, financial corporations and government-backed entities, which respectively account for $21 \%, 20 \%$ and $15 \%$ of the cumulative value of these instruments. It should be added that in 2020 the value of issuance in the public sector increased, while in the private sector it remained unchanged. This results from the fact that public sector issuers are typically less vulnerable to market dynamics (due to COVID-19) because they tend to have long-term investment plans in place. Green bonds are used to finance ventures in various fields. Considering the total amounts obtained from their issue, the largest funds have been allocated to Energy (USD 1,903 billion), Buildings (USD 1,420 bn) and Transportation (USD 997 bn). Nearly $80 \%$ of the obtained funds were spent on these three sectors (Fig. 2). 


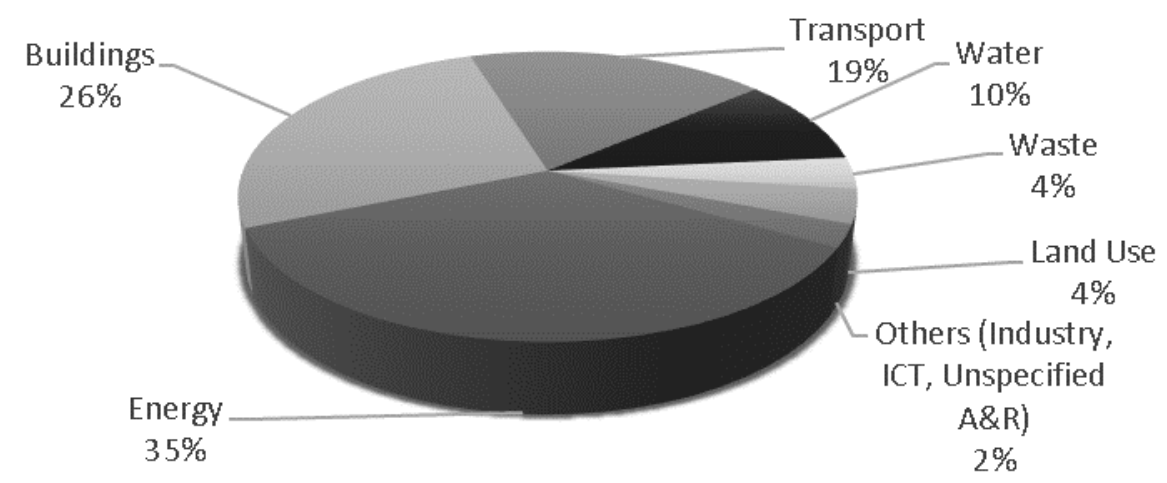

Figure 2. Global cumulative value of green bonds by type of financed enterprise. Source: Climate Bonds Initiative.

Many countries in Europe issue green bonds now, but their cumulative value significantly differentiates them. France and Germany, whose cumulative value of these financial instruments at the end of the first half of 2021 amounted to USD 148 billion and USD 122.4 billion respectively, are undisputed leaders here (Fig. 3). They are followed by the Netherlands (USD 65.8 billion), Sweden (USD 54.1 billion) and Spain (USD 47.4 billion). Poland, with USD 5.9 billion, is much lower in this ranking, close to Austria (USD 6.2 billion) on one side and Switzerland (USD 5.9 billion) on the other.

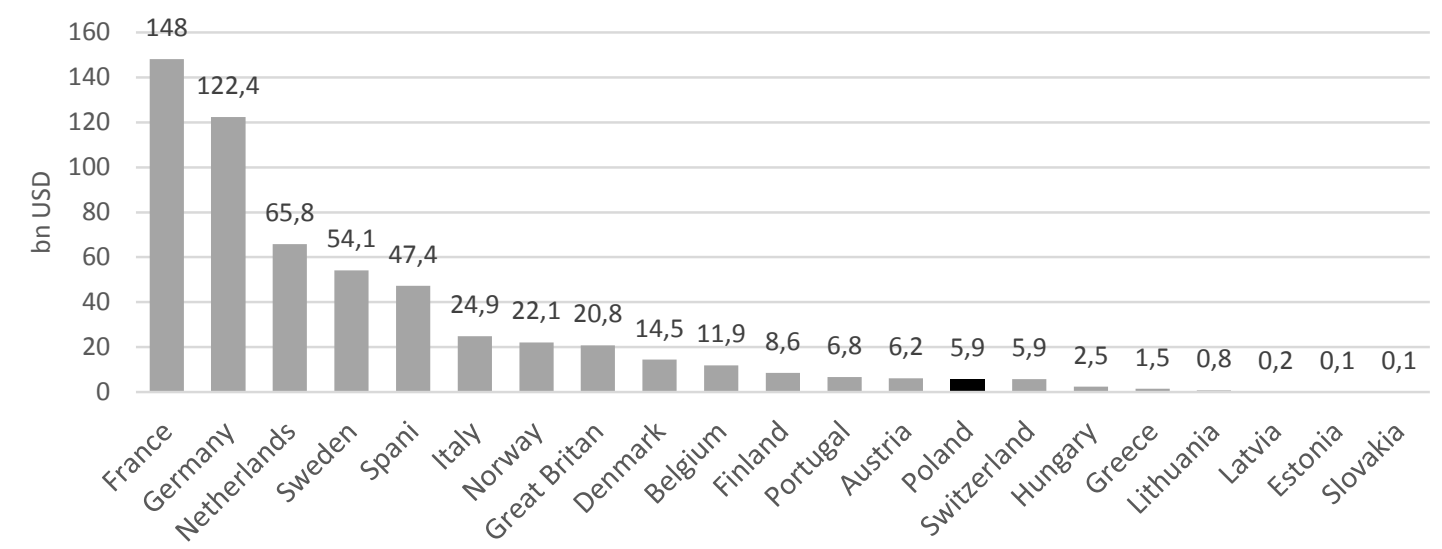

Figure 3. Cumulative value of green bonds in selected European countries. Source: Climate Bonds Initiative.

The main issuers of green bonds on the European market are non-financial corporations, government-backed entities and financial corporations, which respectively account for $25 \%$, $22 \%$ and $21 \%$ of the cumulative value of these instruments. Development Bank (8\%) and Sovereign (16\%) also have a significant share. The share of such issuers as local government or ABS (Asset-backed security) does not exceed 1\%.

As at the global level, also in Europe three main areas financed from "green" emissions can be indicated. $79 \%$ of the obtained funds have been spent on them so far. They include Energy (USD 2,284 billion), Buildings (USD 1,704 billion) and Transportation (USD 1,197 billion). 
Poland, like many other countries in Europe, has issued green bonds. Based on the statistical database collected by the Climate Bonds Initiative, it can be concluded that their cumulative value at the end of the first half of 2021 was USD 5.9 billion, although their level was different in the subsequent years of the analysis (Fig. 4).

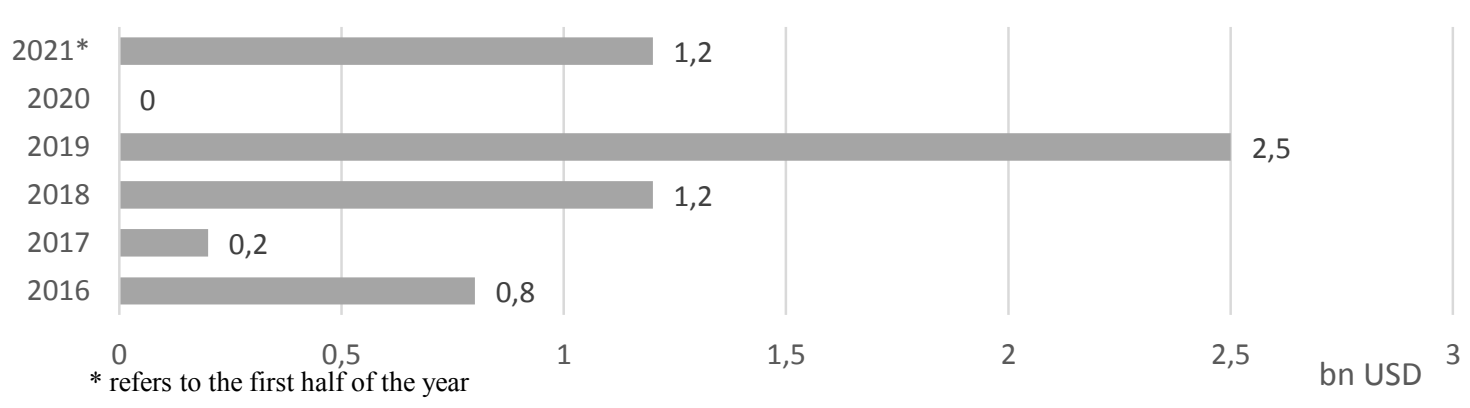

Figure 4. The value of green bonds issued in Poland in 2016-2021. Source: Climate Bonds Initiative.

The first Polish green bonds appeared in 2016, and their issuer was the government. By issuing green treasury bonds, Poland became a precursor in this area. Similar activities were soon implemented by such countries as France, Fiji, Nigeria, Indonesia, Belgium, Lithuania, Ireland, Seychelles, the Netherlands, Hong Kong and Chile (OECD, 2018). Due to the fact that "green" financing is gaining more and more interest - new government issues have appeared. Their synthetic characteristics is presented in Table 3.

Table 3.

Characteristics of green treasury bonds in Poland

\begin{tabular}{|c|c|c|c|c|}
\hline \multirow{2}{*}{ Specification } & \multicolumn{4}{|c|}{ Emission } \\
\hline & 20.12.2016 & 7.02.2018 & 28.02.2019 & 28.02.2019 \\
\hline Tenor (years) & 5 & 8 & 10 & 30 \\
\hline Coupon $(\%)$ & 0.50 & 1.125 & 1.00 & 2.00 \\
\hline Re-offer yield (\%) & 0.634 & 1.153 & 1.06 & 2.07 \\
\hline Size (nominal value) & $750 \mathrm{~m} \mathrm{EUR}$ & 1 bn EUR & $1.5 \mathrm{bn}$ EUR & $500 \mathrm{~m} \mathrm{EUR}$ \\
\hline Demand from investors & 1.5 bn EUR & 3.25 bn EUR & 3.5 bn EUR & $1.3 \mathrm{bn}$ EUR \\
\hline $\begin{array}{l}\text { Sectorial distribution } \\
\text { of the proceeds }\end{array}$ & $\begin{array}{l}\text { Sustainable Agricultural } \\
\text { Operations }(39 \%) \text {, Clean } \\
\text { Transportation }(32 \%) \text {, } \\
\text { Renewable Energy } \\
(21 \%) \text {, others }(8 \%) .\end{array}$ & $\begin{array}{l}\text { Clean Transportation } \\
(77 \%) \text {, Sustainable } \\
\text { Agricultural } \\
\text { Operations }(8 \%), \\
\text { Renewable Energy } \\
(7 \%), \text { others }(8 \%) \text {. }\end{array}$ & $\begin{array}{l}\text { Clean Transpo } \\
\text { Sustainable A\& } \\
\text { Operations }(17 \\
\text { Energy }(12 \%) \text {, }\end{array}$ & $\begin{array}{l}\text { tion }(65 \%) \text {, } \\
\text { ultural } \\
\text {, Renewable } \\
\text { hers }(6 \%) .\end{array}$ \\
\hline
\end{tabular}

Source: elaboration based on: (Ministry of Finance, 2017), (Ministry of Finance, 2019), (Ministry of Finance, 2020).

The bonds are listed on the Luxembourg Stock Exchange on the dedicated green platform - Luxembourg Green Exchange. Analysing the data shown in Table 3, it can be concluded that each time the demand for Polish green treasury bonds definitely exceeded the offered volume of the issues. The success, which was a great interest on the part of bondholders, mainly foreign ones, and positive assessments of rating agencies, resulted in four such issues by the Polish Ministry of Finance. Funds from their emission are primarily directed to projects related to Sustainable Agricultural Operations, Clean Transportation and Renewable Energy. What is left, is used for funding in such areas as: National Parks, afforestation and reclamation of heaps. 
Green bonds of the financial sector are another example of "green" financing in Poland. In 2017, Bank Zachodni WBK (Santander Consumer Bank) launched bonds of ecological profile. It should be mentioned that it was the first case of a green bond issue in Poland by a commercial bank. Subsequent transactions of this type were performed by PKO Bank Hipoteczny and ING Bank Hipoteczny. However, in this case, they were green covered bonds that were the subject of the actions and not strictly green bonds. In Poland, these instruments may only be issued by mortgage banks and Bank Gospodarstwa Krajowego (Stenitzer, 2020).

It is worth adding that all the cited securities have an official green label, i.e., they can be considered Polish green marked bonds.

Yet another example of the issue of green bonds in Poland are those issued by local governments. In 2020, Grudziądz was the first Polish city that obtained finance (PLN 63.2 million) for environmental protection investments in the water and sewage category through the issue of green bonds. Łódź is another city that plans to issue green local government bonds in 2021. The value of the issue is PLN 50 million, which is to be allocated to investments in a low-emission economy and the development of sustainable water and sewage management (uml.lodz.pl).

Grupa Cyfrowy Polsat S.A. operating in the field of telecommunications, new technologies and media is a positive example of the implementation of green corporate bonds in Poland. Green Bonds of Cyfrowy Polsat S.A. were issued in January 2020. The purpose of the issue was to refinance the costs incurred by the capital group in 2017-2019 that were related to their improvement of energy efficiency and reduction of the use of electronic components, and, as a result, reduction of the carbon footprint. The bonds are listed on the Warsaw Stock Exchange, on the Catalyst market. The bonds themselves have not been assigned any ratings. On the other hand, at the time of issuing the Green Bonds, Cyfrowy Polsat S.A. Group had the following ratings: Ba1 (stable) granted by the Moody's Investors Service rating agency and $\mathrm{BB}+$ (positive) granted by S\&P Global Ratings (Grabowski, Kotecki, 2020). Other companies that decided to issue green financial instruments include, for example, PKN ORLEN or New Energy Investments Sp. z o.o. It might seem that entities related to, for example, the energy sector should be especially interested in obtaining funds from green bonds. Meanwhile, as part of a survey conducted by the smart-grids.pl portal, representatives of four energy companies: PGE Polska Grupa Energetyczna SA, Enea SA, Energa SA, Innogy Stoen Operator, answered in a direct or slightly veiled manner that they were not interested in such projects (smartgrids.pl) 


\section{Conclusions}

Today there is no need to convince anyone that we have a global ecological crisis. The effects of climate and environmental change can be disastrous. Many ecologists and scientists including the Nobel Prize winner in economics - J. Stiglitz (2004) are sounding the alarm. He believes that comparing the imminent climate crisis to a global world war is fully justified. In his opinion, the effects of climate change will not resemble anything that humanity has experienced so far. They will be huge, incalculable and tragic for the whole world. Our planet is calling for help like never before, while businessmen, politicians and most of ordinary people do not care about that. Probably when they start doing this, it will not matter anymore.

Despite such a pessimistic opinion, many international organizations (e.g., the UN-Paris Agreement on limiting the threats of climate change or the European Union and the European Green Deal it prepared), governments of various countries, institutions and economic entities make efforts to ensure a better result of limiting environmental changes. The concept of green finance, which may take the form of green loans or capital market products, such as green bonds or green capital investments are an example of such initiatives. Green finances are not a seasonal fashion, but a permanent and irreversible trend in global finances.

The green bond market is a response to the growing needs in the field of pro-ecological investments. As the presented data show, we are observing its dynamic development. On the one hand, it is, unfortunately, a signal of the deteriorating environmental conditions for sustainable development and the need to eliminate the effects of climate and environmental changes, and on the other hand, the growing needs for new investments meeting pro-ecological criteria.

The article highlights the fact that green bonds are usually defined by reference to what they finance, i.e., investments in green technologies, activities and projects, and not by what they achieve, i.e., what their real impact is. Failure to measure this impact on obtaining positive changes in the state of the natural environment may result in "greenwashing". The defined standards of green bonds are to prevent this negative phenomenon. Establishing and common use of the so-called green taxonomy, incorporating green preferences in investment advice, extending the scope of disclosures and integrating sustainability into the rating agencies' methodology is the most important action preventing greenwashing. In particular, the taxonomy is intended to help investors identify sustainable investments and ensure their credibility. It also allows to identify entities that really care about the environment and distinguish them from those that only pretend to care for the environment (De Jong et al., 2019). 
On the other hand, the undoubted advantages of green bonds include (Grabowski, Kotecki, 2020):

- A large variety of issuers and buyers - and thus expanding the sources of funding and potentially limiting fluctuations in demand for bonds.

- Growing demand from investors leading to oversubscription and an increase in the volume of issues.

- Reputational benefits of the issuer.

- Increased credibility of the issuer's sustainable development strategy leading to strengthening the dialogue with investors.

- Tracking the use of impacts and reporting can lead to the improvement of internal management structures through better communication and knowledge sharing between the party responsible for the project and the party managing finances.

\section{References}

1. Act of January 15, 2015, on bonds (consolidated text Dz.U. [Journal of Law] of 2020 item 1208).

2. Bieniok, H. (2020). Zarządzanie biznesem w warunkach błyskawicznie narastających zagrożeń ekologicznych. In: D. Kopycińska, T. Bernat (eds.), Ekonomiczne wyzwania współczesnego świata (pp. 41-52). Łódź: Wydawnictwo SIZ.

3. Caldecott, B.L., Tilbury, J., Carey, C. (2014). Stranded Assets and Scenarios, Discussion Paper, Smith School of Enterprise and the Environment. Oxford: University of Oxford, pp. 3-19.

4. Climate Bonds Initiative (2021), https://www.climatebonds.net/market/data/, 30.08.2021.

5. De Jong, M.D.T., Huluba, G., Beldad, A.D. (2019). Different Shades of Greenwashing: Consumers' Reactions to Environmental Lies, Half-Lies, and Organizations Taking Credit for Following Legal Obligations. Journal of Business and Technical Communication, 34(1), pp. 38-39.

6. Della Croce, R., Kaminker, C., Stewart, F. (2011). The Role of Pension Funds in Financing Green Growth Initiatives. OECD Working Papers on Finance, Insurance and Private Pensions, No. 10. Paris: OECD Publishing, p. 16.

7. Dziawgo, L. (2014). Greening financial market. Copernican Journal of Finance \& Accounting, vol. 3(2), pp. 9-23.

8. European Commission (2021). Proposal for a REGULATION OF THE EUROPEAN PARLIAMENT AND OF THE COUNCIL on European green bonds. Strasburg, p. 25 and further. 
9. Flammer, C. (2019). Green bonds: Effectiveness and implications for public policy. Environmental and Energy Policy and the Economy, vol. 1, pp. 95-128.

10. Fu, J., Li, S., Ng, A.W. (2020). Challenges and Countermeasures in the Development of China's Green Bond Market. In: J. Fu, A.W. Ng (eds.), Sustainable Energy and Green Finance for a Low-carbon Economy: Perspectives from the Greater Bay Area of China (p. 48). Cham: Springer Nature Switzerland AG.

11. Grabowski, M., Kotecki, L. (2020). Zielone obligacje w Polsce. Przewodnik emitenta. Sopot: Centrum Myśli Strategicznych, pp. 102 and following.

12. Höhne, N., Khosla, S., Fekete, H., Gilbert, A. (2012). Mapping of Green Finance Delivered by IDFC Members in 2011. Köln: Ecofys, p. 7.

13. https://alebank.pl/grudziadz-pierwszym-polskim-miastem-ktore-wyemitowalo-zieloneobligacje/, 25.08.2021.

14. https://smart-grids.pl/aktualnosci/finanse/3567-kiedy-polscy-osd-planuj\%C4\%85emisj\%C4\%99-zielonych-obligacji.html, 30.08.2021.

15. https://uml.lodz.pl/aktualnosci/artykul/lodz-jako-pierwsza-wpolsce-wyemitowala-zieloneobligacje-samorzadowe-id42082/2021/7/13/, 30.08.2021.

16. International Capital Market Association (2019). Guidance Handbook. Paris: ICMA, p. 6.

17. Kotecki, L. (ed.) (2020). Zielone finanse w Polsce. Sopot: Wyd. Instytut Odpowiedzialnych Finansów, European Financial Congress, Global Compact Network Poland, Know-How Hub Centrum Transferu Wiedzy, pp. 4-5.

18. Laskowska, A. (2019). Zielone obligacje skarbowe jako sposób finansowania zadań publicznych, CATALLAXY, 4(2), pp. 103-111.

19. Laskowska, A. (2020). Zielone obligacje w Polsce - teoria i praktyka. In: L. Kotecki (ed.), Zielone finanse w Polsce (pp.47-57). Sopot: Wyd. Instytut Odpowiedzialnych Finansów, European Financial Congress, Global Compact Network Poland, Know-How Hub Centrum Transferu Wiedzy.

20. Lindenberg, N. (2014). Definition of Green Finance, https://www.cbd.int/financial/gcf/ definition-greenfinance.pdf, 10.08.2021.

21. Ministry of Finance (2017). Green Bond Report on the use of Proceeds, p. 5 and following. 22. Ministry of Finance (2019). Green Bond Report on the use of Proceeds, p. 4 and following. 23. Ministry of Finance (2020). Green Bond Report on the use of Proceeds, pp. 3-5.

24. OECD (2018). OECD Sovereign Borrowing Outlook. Paris: OECD Publishing, p. 54.

25. Pricewaterhouse Coopers Consultants (PWC) (2013). Exploring Green Finance Incentives in China, p. 15.

26. Ryszawska, B. (2020). Sustainable finance - paradigm shift, https://postwzrost.pl/wpcontent/uploads/2020/09/Ryszawska-Sustainable-finance-paradigm-shift.pdf, 20.08.2021, p. 11. 
27. Stenitzer, S. (2020). Grüne Anleihen als Instrument gegen den Klimawandel in Österreich: Status quo und Entwicklungsmöglichkeiten. In: A. Sihn-Weber, F. Fischler (eds.), CSR und Klimawandel (p. 210). Wiesbaden: Springer Gabler.

28. Świeszczak, M. (2020). How Are Banks Doing on Sustainable Finance? Finanse i Prawo Finansowe, 3(27), p. 144.

29. Volz, U., Böhnke, J., Knierim, L., Richert, K., Roeber, G., Eidt, V. (2015). Financing the Green Transformation: How to Make Green Finance Work in Indonesia. London: Palgrave Macmillan.

30. WEF (2020). https://www.weforum.or/agenda/2020/11/what-is-green-finance/, 12.08.2021. 31. World Bank (2015). What are green bonds? Washington: World Bank Group, p. 23. 